\title{
Production and Characterization of Spray Dried Protein Hydrolysate from Kidney Bean ( (Phaseolus L. Vulgaris) ) Prepared by Enzymatic Hydrolysis
}

\author{
Sri Priatni ${ }^{*}$, Amelia Adinda ${ }^{2}$, Efendi Oulan ${ }^{2}$, Wawan Kosasih ${ }^{1}$, Rohmatussolihat ${ }^{3}$ \\ ${ }^{1}$ Research unit for clean technology LIPI, Jl. Sangkuriang Bandung, Indonesia 40135 \\ ${ }^{2}$ Surya University, Jl. MH. Thamrin Banten ID, Jl. MH. Thamrin, Panunggangan Utara, Kec. Pinang, Kota \\ Tangerang, Banten Indonesia 15143 \\ ${ }^{3}$ Biotechnology LIPI, Jl. Raya Bogor Km 46, Cibinong, Bogor, Jawa Barat, 16911
}

\begin{abstract}
Protein hydrolysate from kidney bean (Phaseolus L. vulgaris) has been prepared by enzymatic hydrolysis process using papain enzyme. Evaluation of the extent of protein hydrolysis was conducted by measuring the degree of hydrolysis (DH). The optimization of protein hydrolysate production has been carried out by analyzing the influences of papain enzyme concentration, temperature, and time of hydrolysis on the degree of hydrolysis (DH) using RSM Design. The optimized product was spray-dried and analyzed the proximate (moisture, lipid, protein) content. The protein hydrolysate powder product was characterized the foaming capacity and stability, and also by FTIR, and DSC methods. The optimum condition of enzymatic hydrolysis of kidney bean protein was obtained by an addition $3.0 \%$ of papain enzyme at $58^{\circ} \mathrm{C}$ for 7 hours. The functional groups present in the kidney bean protein hydrolyzate are amine group, amino, carboxyl; $\mathrm{C}-\mathrm{O}$, based on the thermal test, there is a peak point of the 7S protein (vicilin) and 11S (legumin), DH of powdered protein hydrolyzate is $6.30 \%$ and the liquid hydrolysate is $7.06 \%$. The highest foaming capacity and stability of this product was reached at $\mathrm{pH}$ 3.0. DSC analysis of the product showed two peaks (Tm) at $66.2^{\circ} \mathrm{C}$ and $105.6^{\circ} \mathrm{C}$.
\end{abstract}

Keyword: Protein, Hydrolysate, Phaseolus L. vulgaris, papain, RSM. 


\section{Introduction}

Kidney beans commonly referred to as Phaseolus vulgaris $L$ are Legume types are very important in human consumption. Red beans already cultivated 70,000 years ago and plays an important role in traditional food people in various regions of the world (Thapa, 2012). Kidney beans are a type plants that are not native to Indonesia, but rather from the west southwest Mexico, South America and mainland China. Furthermore this plant spreads to other regions in the world including Indonesia. Although this plant is not native to Indonesia, but is often found in Indonesia. Many areas in Indonesia Planted with these plants are Lembang, Pacet, Batu City, and Lombok Island (Praptiningrum, 2015). Hydrolysis of protein by strong acids, strong bases or proteolytic enzymes resulting in the form of amino acids and peptides. Hydrolysis with a strong acid is nonspecific and attack all peptide bonds, produces a large number of fragments (Al- Bahri et al. 2009). Enzymatic hydrolysis of protein is the alternative process to improve its functional properties without influencing the nutrition value. The nutritional and functional properties such as solubility, foaming and emulsion stability were improved by enzymatic hydrolysis. Some studies reported the advantage of hydrolyzed protein in human health such as less allergenic, easy digested and absorbed (Kain et al. 2009). Hydrolysis of protein increased the number of peptides and the hydrophobic of amino acid residues would contribute to the formation of the emulsion. Fish protein hydrolysate products have been used as nutritional supplements (Prabha et al. 2016). The functional properties of rapeseed protein have been improved by using different enzymes. Nitrogen solubility, foaming properties, water and fat adsorption capacity of rapeseed meal are improved after hydrolysis by Ficin enzyme. Meanwhile, Oil adsorption capacity, foaming and emulsifying properties of this protein can be improved after hydrolysis with alcalase (G. Chabanon et al. 2007). The objective of this study was to produce the protein hydrolysate (FPH) from kidney beans using papain enzyme and to characterize the spray-dried of FPH product both physical and chemical properties.

\section{Materials and Methods}

\section{Materials}

Kidney beans were purchased at a traditional market in Bandung, Indonesia. Commercial papain enzyme (brand Xian Arisun ChemParm Co. Ltd, CAS no. 2323.627-2, Shaanxi, China) in the form of powder. All chemicals used were of analytical grade.

\section{Preparation of protein hydrolysate (PH)}

PH preparation was carried out by using a modification of Priatni, et al. (2017) and Anissa, et al. (2017) methods. The kidney bean was cleaned and mixed with distilled water with a ratio of 1:4. Samples were blended and $\mathrm{pH}$ adjusted to 7.0. The optimization of $\mathrm{PH}$ production was carried out in a water bath by using $2.0-3.0 \%$ of papain at $40-60^{\circ} \mathrm{C}$ for $3-7 \mathrm{hr}$. The enzymatic hydrolysis process was stopped at $85^{\circ} \mathrm{C}$ and allowed to stand for $15 \mathrm{~min}$. PH extract was 
vacuum-filtrated and the filtrate was stored at $-20^{\circ} \mathrm{C}$. For product characterization purposes, the filtrate sample was spray dried at $160^{\circ} \mathrm{C}$ (inlet) and $80^{\circ} \mathrm{C}$ (outlet).

\section{Optimization of enzymatic hydrolysis condition of PH by RSM-CCD method}

RSM-CCD (Response Surface Methodology - Central Composite Design) was used to predict the optimal hydrolysis condition for $\mathrm{PH}$ using papain enzyme. Optimization of enzymatic hydrolysis was used three factors i.e. the influences of enzyme concentration, temperature and hydrolysis time. Percentage of degree hydrolysis $(\% \mathrm{DH})$ was used as a parameter of hydrolysis. Twenty hydrolysis trials were randomly run per CCD. The center value was selected according to references which are $0.3 \%$ papain enzyme, $55^{\circ} \mathrm{C}$ and 5 hours (Silpradit K et al. 2010, Sathish \& Murthy, 2009, Auwal et al. 2017). Design Expert 7.0 software was used in this experimental design. The optimum condition was used for PH powder production that prepared by spray-dried the supernatant of $\mathrm{FPH}$ with inlet temperature $160^{\circ} \mathrm{C}$ and outlet temperature $80^{\circ} \mathrm{C}$.

\section{Proximate analysis and yield of $\mathrm{PH}$ powder}

The moisture, protein, fat and ash content of PH powder were determined according to AOAC (2002). Soluble protein content was analyzed by using a modification of Lowry method. The yield of FPH powder was calculated by using the following formula:

$$
\text { yield }(\%)=\frac{\mathrm{W} 2}{\mathrm{~W} 1} \times 100 \%
$$

$\mathrm{W} 2=$ mass of FPH powder

$\mathrm{W} 1=$ mass of eel fish fillet

\section{Determination of Degree Hydrolysis}

Degree hydrolysis $(\mathrm{DH})$ of peptone extract was calculated using the relationship between $\alpha$ amino nitrogen (AN) and total nitrogen (TN) according to equation [10]:

$$
\% \mathrm{DH}=\frac{\alpha-\text { amino nitrogen }(\mathrm{AN})}{\text { Total nitrogen }} \times 100
$$

Total nitrogen was determined by Kjeldahl method. $\alpha$-Amino nitrogen was analyzed using a modification of Wang et al. (2012) method. The concentration of $\alpha$-AN was calculated using the following equation:

$$
\alpha-A N(\%)=\frac{V}{W \times 10} \times N \text { NaoH } \times 14.008
$$

$\mathrm{V}$ : titration volume, W: the weight of the sample.

\section{Foaming capacity and stability}

The foaming capacity and stability of PH from the powder sample were determined according to Naqash and Nazeer (2013) method with modification. The foaming capacity was calculated as, 
Where,

$$
\text { foaming capacity }(\%)=\frac{(\mathrm{A}-\mathrm{B})}{\mathrm{B}} \times 100 \%
$$

A is the volume after whipping $(\mathrm{ml})$

$\mathrm{B}$ is the volume before whipping $(\mathrm{ml})$

Foam stability was calculated as follows:

$$
\text { foaming stability }(\%)=\frac{(\mathrm{A}-\mathrm{B})}{\mathrm{B}} \times 100 \%
$$

\section{Fourier transforms infrared spectroscopy (FTIR)}

The functional group of FPH powder sample has been analyzed by FTIR (Thermo Scientific, Nicolet iS5 iD5 ATR) technique according to Rosli and Sarbon's (2015) method with modification. The FTIR spectra were obtained from discs contained FPH powder in potassium bromide (KBr). Duplicates samples were analyzed and spectra from 4000 to $550 \mathrm{~cm}^{-1}$ were obtained at a data acquisition rate of $4 \mathrm{~cm}^{-1}$ at room temperature. The functional group of FPH was monitored from the spectra and compared to references data. The peaks obtained from the spectra of samples were assigned based on functional groups present in the sample.

\section{Determination of melting temperature}

FPH powder sample melting temperature $(\mathrm{Tm})$ was determined by a differential scanning calorimetry (DSC) technique (Netzsch, DSC214), according to Ren et al. (2010) method with modification. The samples were filled in a pan, weighed and pressed by a hydraulic handle. Samples were analyzed at a heating rate of $10^{\circ} \mathrm{C} / \mathrm{min}$ ranging from 20 to $12^{\circ} \mathrm{C}$. The transition midpoint ( $\mathrm{Tm}$, or the melting temperature) is the temperature at which half the protein molecules are folded and half are unfolded.

\section{Results and Discussion}

The optimization of the hydrolysis process of PH from kidney beans was determined according to the percentage of the degree hydrolysis $(\% \mathrm{DH})$. The optimization of enzymatic hydrolysis was analyzed by RSM-CCD design. Analysis of variance (ANOVA) of the response surface quadratic model for DH of PH was presented in Table 1. Overall data showed that the model had significant $(\mathrm{p}<0.05)$ with $\mathrm{R}^{2}$ value was 0,8269 . 
Table 1. Analysis of variance (ANOVA) of degree hydrolysis PH

\begin{tabular}{|c|c|c|c|c|c|c|}
\hline Source & $\begin{array}{l}\text { Sum of } \\
\text { squares }\end{array}$ & df & $\begin{array}{l}\text { Mean } \\
\text { Square }\end{array}$ & FValue & $\begin{array}{l}\text { p-value } \\
\text { Prob }>\text { F }\end{array}$ & \\
\hline Model & 9.028034 & 9 & 1.003115 & 5.30708 & 0.0077 & significant \\
\hline $\mathrm{X}_{1}$-temp. & 2.536197 & 1 & 2.536197 & 13.41801 & 0.0044 & \\
\hline$X_{2}$-time & 2.625625 & 1 & 2.625625 & 13.89113 & 0.0039 & \\
\hline $\mathrm{X}_{3}$-Konsentrasi & 1.300598 & 1 & 1.300598 & 6.880945 & 0.0255 & \\
\hline $\mathrm{X}_{1} \mathrm{X}_{2}$ & 0.016833 & 1 & 0.016833 & 0.089056 & 0.7715 & \\
\hline $\mathrm{X}_{1} \mathrm{X}_{3}$ & 0.016833 & 1 & 0.016833 & 0.089056 & 0.7715 & \\
\hline $\mathrm{X}_{2} \mathrm{X}_{3}$ & 0.046758 & 1 & 0.046758 & 0.247378 & 0.6297 & \\
\hline Lack of Fit & 1.348375 & 5 & 0.269675 & 2.488837 & 0.1698 & not significant \\
\hline $\mathrm{X}_{1}^{2}$ & 0.523202 & 1 & 0.523202 & 2.768053 & 0.1271 & \\
\hline $\mathrm{X}_{3}^{2}$ & 1.792885 & 1 & 1.792885 & 9.485439 & 0.0116 & \\
\hline $\mathrm{X}_{2}^{2}$ & 0.584263 & 1 & 0.584263 & 3.091102 & 0.1092 & \\
\hline Residual & 1.890144 & 10 & 0.189014 & & & \\
\hline Pure Error & 0.541769 & 5 & 0.108354 & & & \\
\hline Cor Total & 10.91818 & 19 & & & & \\
\hline
\end{tabular}

Table 1 shows the ANOVA analysis of the degree of hydrolysis response using a quadratic model. Based on the data, it can be seen that the quadratic model used has a $p$ value of 0.0077 ( $\mathrm{P}<0.05)$ so that the model used has significant value. The independent variable is used are temperature, time and concentration of the enzyme papain, these three variables has a value of $0.0044 ; 0.0039 ; 0.0255$, respectively. These three variables are used has a $\mathrm{P}$ value $<0.05$ so that it has a significant value.Lack of fit from the quadratic model degree of hydrolysis of red bean protein is $0.1698(\mathrm{P}>0.05)$ which means it has not significant value. This indicates that the quadratic model is suitable to be used to determine the optimum conditions for the hydrolysis of the red bean protein. The equation for $\mathrm{DH}$ and the response variable (Y) of $\mathrm{PH}$ was derived 
using the regression coefficient of intercept, linear, enzyme concentration, time and quadratic terms to fit a full response surface model. The equation was given as follow:

$$
\mathrm{Y}=5.5709+0.4309 \mathrm{X}_{1}+0.4385 \mathrm{X}_{2}+0.3083 \mathrm{X}_{3}+0.3527 \mathrm{X}_{3}^{2}
$$

Figure 1. 3D surface plot of interaction between temperature and time (a), temperature and concentration (b), time and concentration (c) factors on degree hydrolysis (DH) of PH from kidney beans

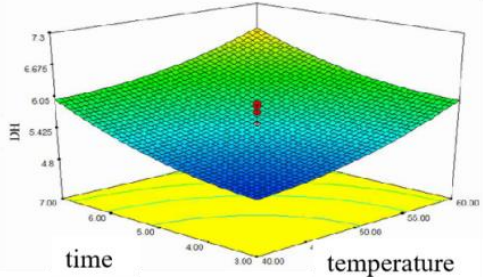

a

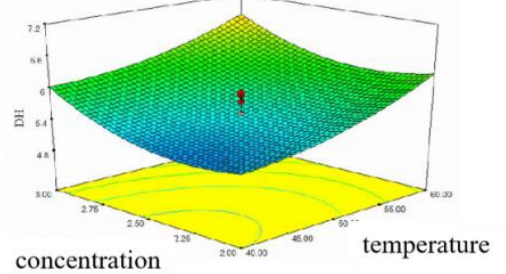

b

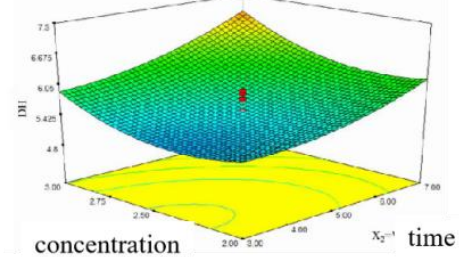

c

On graph 1a shows the effect of temperature and time in degree of hydrolysis. Based on the graph above, it can be seen that the maximum $\mathrm{DH}$ can be obtained at the reaction time the longer it is used as well as the temperature.In the contour plot analysis, DH will have a high value when using the reaction time between 6 to 7 hours and the temperature used is between 55 to $60^{\circ} \mathrm{C}$. Graph $1 \mathrm{~b}$ shows the effect of temperature and papain enzyme concentration in the degree of hydrolysis.Plot contour analysis shows that $\mathrm{DH}$ will have a high value at the time using the concentration of the papain enzyme at levels $2.75 \%$ to $3 \%$ and temperature used is between 55 to $60^{\circ} \mathrm{C}$. Meanwhile, graph 1c showing the influence of time and Papain enzyme concentration in the degree of hydrolysis.based on this analysis, the degree of hydrolysis (DH) produced has a range between $4,893 \%$ to $7,217 \%$. The optimization process using expert design software.The independent variables used are temperature, papain enzyme concentration and temperature with the percentage of $\mathrm{DH}$ as the response to produce the combination of model. Based on the data, the optimum condition of enzymatic hydrolysis of kidney beans protein was obtained by an addition $3.0 \%$ of papain enzyme at $58^{\circ} \mathrm{C}$ for 7 hours. The predicted value of the degree of hydrolysis of red bean protein is $7,284 \%$.

Figure 2. FTIR spectra of PH from kidney beans

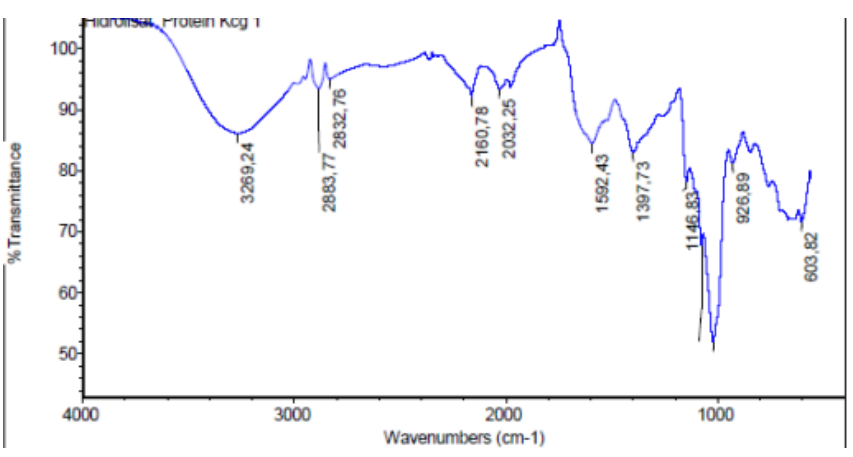


From FTIR spectra (Figure 2) was identified 9 absorption, there is 1 strong band, 2 medium bands, 1 shoulder band and 5 weak bands. Strong band that is absorb at $3263.7 \mathrm{~cm}^{-1}$; medium band i.e. absorb of $1591.55 \mathrm{~cm}^{-1} ; 1397.66 \mathrm{~cm}^{-1} ; 1$ shoulder band is the absorption of 1146.85 $\mathrm{cm}^{-1} ; 5$ weak bands namely $2883.92 \mathrm{~cm}^{-1} ; 2160.88 \mathrm{~cm}^{-1} ; 2033.33 \mathrm{~cm}^{-1} ; 665.28 \mathrm{~cm}^{-1} ; 598.11 \mathrm{~cm}^{-}$ ${ }^{1}$. The strong band in the absorption is the bond of $\mathrm{O}-\mathrm{H}$ and $\mathrm{N}-\mathrm{H}$. This is because the two bonds are between $3000-3700 \mathrm{~cm}^{-1}$. In this absorption is indicated as a group amine, this is because the amine will show clear at $3000-3700 \mathrm{~cm}^{-1}$ and to the left of the $\mathrm{C}-\mathrm{H}$ absorption. This is proven by the existence absorption $2883.92 \mathrm{~cm}^{-1}$ which is a stretching band/CH. Absorption at $1591.55 \mathrm{~cm}^{-1}$ represents $\mathrm{CH}-\mathrm{NH}_{2}$ or an amino group and absorption $1397.66 \mathrm{~cm}^{-1}$ is a $\mathrm{COOH}$ bond or carboxyl group, this group was suggested as the amino acid. This is due to of amino acids are monomers protein consisting of amino groups and carboxyl groups. Moreover, this also proves that the hydrolysis process of in the preparation of protein hydrolysate the complex bonds of proteins can produced the amino acids (Belitz, Grosch, \& Schieberle, 2009). Absorption at $1146.85 \mathrm{~cm}^{-1}$ is a ribbon stretching / stretching C-O an at $2160.88 \mathrm{~cm}^{-1}$ and $2033.33 \mathrm{~cm}^{-1}$, represent the existing bands caused by the diamond used on the FTIR. While the two absorption is $665.28 \mathrm{~cm}^{-1}$ and $598.11 \mathrm{~cm}^{-1}$ are the fingerprint area (Ven, et al., 2002).

Figure 3. Profiles of the Foaming Capacity (a) and Foaming Stability (b) at different $p H$ values of PH from kidney beans
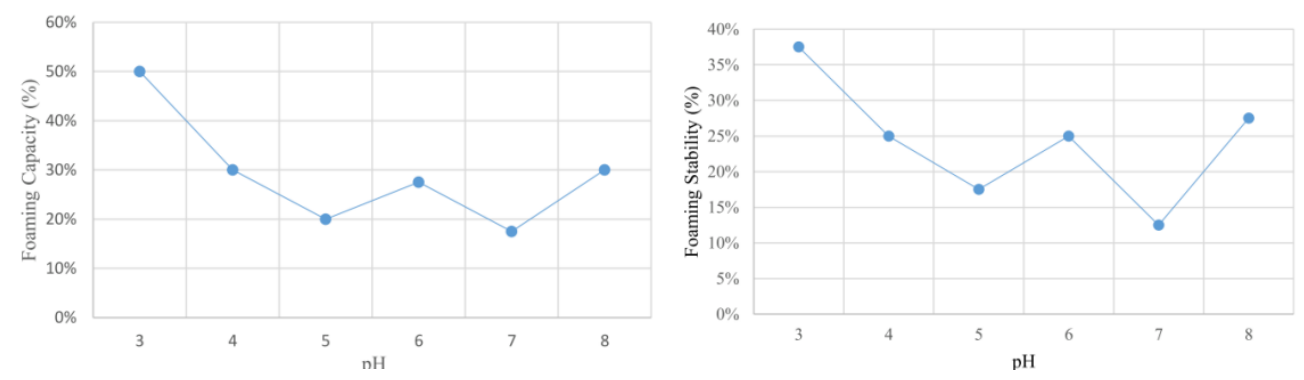

The results analysis of foam capacity and foam stability are presented in Figure 3 . The data shows that the highest of foam capacity (50\%)and foam stability (38\%)of red bean protein hydrolysate were at $\mathrm{pH}$ 3.Foam capacity is associated with the level of flexibility of protein. Protein will diffuses faster into the air-water interface to wrap the particles of air which will ultimately increase the foam capacity (Deng, et al., 2011).This study suggested that protein hydrolysate from kidney beans contain aspartic acid or glutamic acid due to both of these amino acids have an isoelectric point at a pH around 3 (Wade, 2006). Foam stability will have a higher value on $\mathrm{pH}$ close to the isoelectric point of the protein. This is due to attraction intermolecular 
$2^{\text {nd }}$ International Conference on Modern Research in

electrostatic resulting a maximum $\mathrm{pH}$ value that increasing the stiffness and thickness of protein adsorbed on interface between air and water (Kempka, Horvath, Fagundes, \& Prestes, 2015).

Figure 4. DSC thermogram of PH from kidney beans

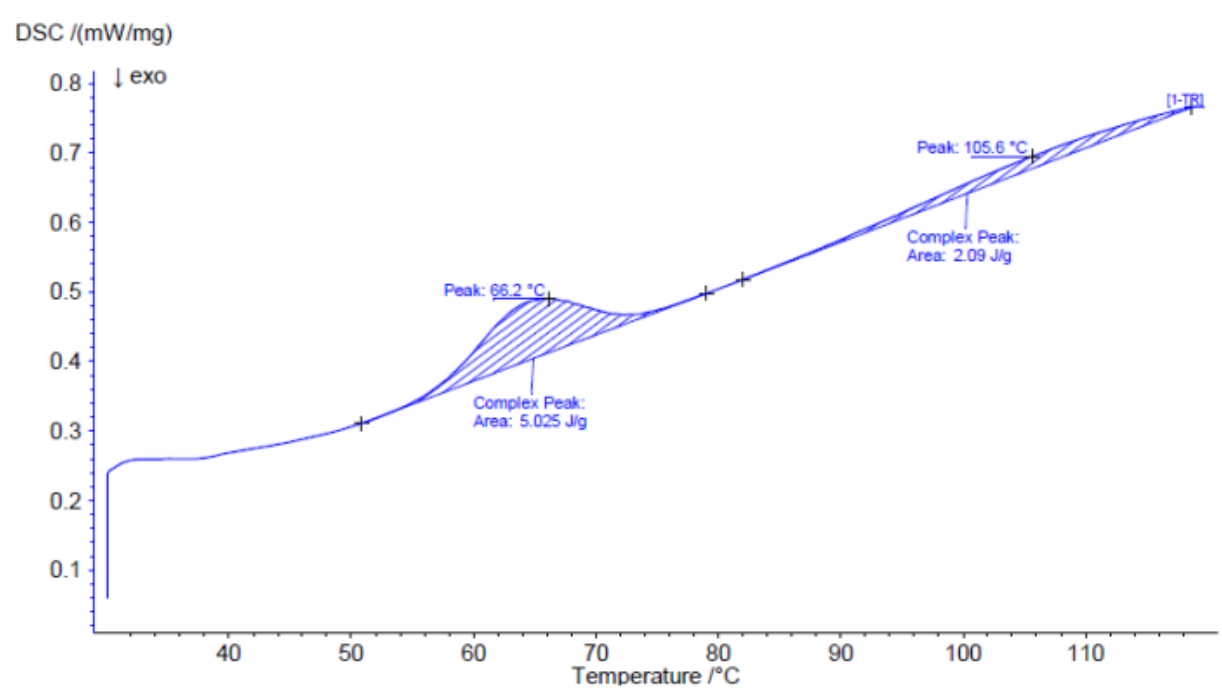

Differential Scanning Calorimeter (DSC) analysis is the method to analyze the denaturation temperature of food protein. This method is very important for food protein application. The results analysis of hydrolysate powder red bean protein was presented in Figure 4. the data shows there are two peaks which are $66.2^{\circ} \mathrm{C}, 5.0 \mathrm{H}$ with $\Delta \mathrm{H} 5,025 \mathrm{~J} / \mathrm{g}$ and $105.6 \mathrm{C}$ and with $\Delta \mathrm{H} 2.09 \mathrm{~J} / \mathrm{g}$. The first denaturation temperature or peak point value of red bean $\mathrm{PH}$ can be related to the denaturation of $7 \mathrm{~S}$ (vicilin) and the second peak related with $11 \mathrm{~S}$ (legumin) globulin, which is the dominant protein in beans (Parra, 2018). $\Delta \mathrm{H}$ is a value both exothermic and endothermic contributions due to the breakdown of hydrophobic bonds and hydrogen. This correlates with the contents of the secondary structure of the protein. The difference of $\Delta \mathrm{H}$ value is influenced by hydrolysis time which indicated that the product will be stabilized by hydrogen bonds and hydrophobic interactions (Ortiz \& Añón, 2001).

\section{Conclusion}

The outcome of this study shows the potential usage of kidney beans for the production of $\mathrm{PH}$ through the enzymatic hydrolysis using papain enzyme and serves as a protein supplement. 
The structural analysis of the $\mathrm{PH}$ product found the presence of amine groups and carboxyl group related to the existence of amino acids. Foam capacity and foam stability analysis suggested that protein hydrolysate from kidney beans contain aspartic acid or glutamic acid due to both of these amino acids have an isoelectric point at a $\mathrm{pH}$ around 3. The denaturation temperature of red bean protein hydrolysate is related to the denaturation of $7 \mathrm{~S}$ (vicilin) and $11 \mathrm{~S}$ (legumin) globulin.

\section{Acknowledgment}

This paper is an output of the science project in Research Unit for Clean Technology Indonesian Institute of Sciences (LIPI).

\section{References}

[1] Al-bahri, Mohammed B A G, Safa A Al-naimi, and Sundus H Ahammed. (2009). "The Optimum Conditions for Production of Soya Peptone by Acidic Hydrolysis of Soya Proteins." Al-Khwarizmi Engineering Journal 5(1): 1-19.

[2] Amri, Ezekiel, and Florence Mamboya. (2012). Papain , a Plant Enzyme of Biological Importance : a Review.American Journal of Biochemistry and Biotechnology 8(2): 99-104.

[3] AOAC (1995). Official Methods of Analysis of The Association Official Analytical Chemistry, Washington DC

[4] Carić M, (1994). Concentrated and dried dairy products. VCH Publishers Inc, New York, USA.

[5] Chabanon, G., Chevalot, I., Framboisier, X., Chenu, S., \& Marc, I. (2007). Hydrolysis of rapeseed protein isolates: Kinetics, characterization and functional properties of hydrolysates. Process Biochemistry, 42, 1419-1428. https://doi.org/10.1016/j.procbio.2007.07.009

[6] Deng, Q., Wang, L., Wei, F., Xie, B., Huang, F., Huang, W., ... Xue, S. (2011). Functional properties of protein isolates, globulin and albumin extracted from Ginkgo biloba seeds. Food Chemistry 124, 1458-1465.

[7] Gill, P., Moghadam, T. T., \& Ranjbar, B. (2010). Differential Scanning Calorimetry Techniques: Applications in Biology and Nanoscience. 167-193.

[8] Hassan, A., Martin, R. P. D. K. A., Subodh, X., Binaya, G., \& Nayak, B. (2019). Evaluation of the Properties of Spray Dried Visceral Protein Hydrolysate from Pangasianodon hypophthalmus ( Sauvage, 1978 ) Extracted by Enzymatic and Chemical Methods. Waste and Biomass Valorization, 10(9), 2547-2558. https://doi.org/10.1007/s12649-018-0302-1

[9] John, H., Mansuri, S. M., Giri, S. K., \& Sinha, L. K. (2018). Rheological Properties and Particle Size Distribution of Soy Protein Isolate as Affected by Drying Methods. Nutrition \& Food Science International Journal, 7(5).

https://doi.org/10.19080/NFSIJ.2018.07.555721 
[10] Kain R.J., Chen Z., Sonda T.S., Kpawoh J.C.A., (2009). Study on the effects of enzymatic hydrolysis on the physical, functional and chemical properties of peanut protein isolates extracted from defatted heat pressed peanut meal flour (Arachis hypogaea L.). Pakistan Journal of Nutrition 8(6): 818-825

[11] Kempka, A. P., \& Prestes, R. C. (2015). Foaming And Emulsifying Capacity, Foam and Emulsion Stability of Proteins of Porcine Blood : Determination at Different Values of $\mathrm{pH}$ and Concentrations.Revista Brasileira de Tecnologia Agroindustrial. 1797-1809.

[12]Levitsky, D. I., Pivovarova, A. V, Mikhailova, V. V, \& Nikolaeva, O. P. (2008). Thermal unfolding and aggregation of actin Stabilization and destabilization of actin filaments. FEBS Journal, 275, 4280-4295. https://doi.org/10.1111/j.1742-4658.2008.06569.x

[13] Ortiz, S. E., \& Añón, M. C. (2001). Enzymatic Hydroliysis of Soy Protein Isolates : DSC Studies. Journal of Thermal Analysis and Calorimetry, Vol. 66, 489-499.

[14]Parra, M. J. (2018). Lentil protein: a review of functional properties and food application. An overview of lentil protein functionality. International Journal of Food Science and Technology 53, 892-903.

[15] Praptiningrum, W. (2015). Eksperimen Pembuatan Butter Cookies Tepung Kacang Merah Substitusi Tepung Terigu. Semarang: Universitas Negri Semarang.

[16] Priatni, S., Kosasih, W., Budiwati, T.A., dan Ratnaningrum, D. (2016). Production of Peptone from Boso Fish (Oxyeleotris marmorata) for Bacterial Growth Medium. IOP Conference Series: Earth and Environmental Science, 60.

[17]Ren, J., Wang, H., Zhao, M., Cui, C., \& Hu, X. (2010). Enzymatic Hydrolysis of Grass Carp Myofibrillar Protein and Antioxidant Properties of Hydrolysates. Czech J. Food Sci., 28(6), 475-484.

[18] Samsudin, N. A.Halim, N. R. A. Sarbon, N. M. (2018). PH levels effect on functional properties of different molecular weight eel (Monopterus sp.) protein hydrolysate. Journal of Food Science and Technology, 55(11), 4608-4614. https://doi.org/10.1007/s13197-018$3399-0$

[19] Silpradit, K., Tadakittasarn, S., Rimkeeree, H., Winitchai, S., \& Haruthaithanasan, V. (2010). Optimization of rice bran protein hydrolysate production using alcalase. Asian Journal of Food and Agro-Industry 3(02), 221-23.

[20] Thapa, a. R. (2012). Effect of Tempering and Other Processing Treatments on the Antinutritional Factors and a Canning Quality Attribute of Dark Red Kidney Beans. Wisconsin: University of Wisconsin-Stout.

[21] Ven, C. v., Muresan, S., Gruppen, H., Bont, D. B., Merck, K. B., \& Voragen, A. G. (2002). FTIR spectra of whey and casein hydrolysates in relation to their functional properties. Journal of Agricultural and Food Chemistry, 91-104. 
$2^{\text {nd }}$ International Conference on Modern Research in

[22] Wang, Haiyan et al. (2012). "Comparison of Chromatographic and Titrimetric Methods for the Determination of the $\alpha$-Amino Nitrogen in Standard Solution and Fish Protein Hydrolysates." J Food Research; 1(4): 174-83.

[23] Wisuthiphaet, N., \& Kongruang, S. (2015). Production of Fish Protein Hydrolysates by Acid and Enzymatic Hydrolysis. Journal of Medical and Bioengineering, 4(6), 466-470. https://doi.org/10.12720/jomb.4.6.466-470 